\title{
sciendo
}

RESEARCH PAPERS FACULTY OF MATERIALS

SCIENCE AND TECHNOLOGY IN TRNAVA

SLOVAK UNIVERSITY OF TECHNOLOGY

IN BRATISLAVA

2019, Volume 27, Number 44

DOI 10.2478/rput-2019-0016

\section{OPTIMIZATION OF TWO-STEP ALKALI PROCESS OF LIGNIN REMOVAL FROM BASSWOOD}

\author{
Igor WACHTER ${ }^{1}$, Tomáš ŠTEFKO ${ }^{1}$, Marek ROLINEC ${ }^{1}$ \\ ${ }^{1}$ SLOVAK UNIVERSITY OF TECHNOLOGY IN BRATISLAVA, \\ FACULTY OF MATERIALS SCIENCE AND TECHNOLOGY IN TRNAVA, \\ INSTITUTE OF INTEGRATED SAFETY \\ ULICA JÁNA BOTTU 2781/25, 91724 TRNAVA, SLOVAK REPUBLIC \\ e-mail: igor.wachter@stuba.sk, tomas.stefko@stuba.sk, marek.rolinec@stuba.sk \\ Received: 17.05.2019, Accepted: 14.06.2019, Published: 22.07.2019
}

\begin{abstract}
The aim of the research described in this article was to optimize the basic sulphur process of lignin removal from the raw radially cut basswood (Tilia Cordata) pieces of various thicknesses. Lignin removal took place chemically in several consecutive steps in which the influence of individual parameters was investigated (solutions of $\mathrm{NaOH}+\mathrm{Na}_{2} \mathrm{SO}_{3}, \mathrm{KOH}+$ $\mathrm{Na}_{2} \mathrm{SO}_{3}$, its concentrations, time of leaching, efficacy of whitening agents, effect of sample washing between individual baths, etc.). Through experiments, it was found that the change of fresh $\mathrm{NaOH}+\mathrm{Na}_{2} \mathrm{SO}_{3}$ solution during the experiment had no significant effect. In contrast, skipping the washing of the samples with boiling distilled water after the hydroxide bath had a significant effect on the rate and efficiency of lignin removal with $\mathrm{H}_{2} \mathrm{O}_{2}$ in the following step. When comparing the lignin removal efficiency of $\mathrm{NaOH}+\mathrm{Na}_{2} \mathrm{SO}_{3}$ and $\mathrm{KOH}+\mathrm{Na}_{2} \mathrm{SO}_{3}$, the delignification process was clearly demonstrated to be more effective using the $\mathrm{KOH}+\mathrm{Na}_{2} \mathrm{SO}_{3}$ solution. Application of the above-mentioned procedures has helped to streamline the lignin removal process from solid basswood.
\end{abstract}

Key words

Cellulose $\cdot$ basswood $\cdot$ lignin removal $\cdot$ optimization $\cdot$ transparent wood

\section{INTRODUCTION}

Wood is considered to be a versatile material used in many different sectors and industries from which the construction industry occupies a significant part of the total usage owing to its excellent mechanical properties and a potential to sequester carbon dioxide [1].

Since the industrial revolution, humans have transformed carbon containing resources into $\mathrm{CO}_{2}$ such as coal, oil, and natural gas. During this period, it is estimated that $5.4 \mathrm{Gt}$ of $\mathrm{CO}_{2}$ were produced [2]. 
Depending on their types and geographical differences, different woods display an extraordinary variety of mesostructures [3].

Wood possesses a cellular, three-dimensional microstructure and is described as a natural composite material with orthotropic elastic properties. Mechanical properties of the wood cell wall, comprised of primary and secondary cell wall layers, are dictated by the orientation of stiff cellulose micro fibrils in a matrix of hemicellulose and lignin. The orientation of micro fibrils has a direct influence on elastic properties of the wood cell wall and varies as a function of position in the tree and within annual rings [4].

Lignin is an amorphous non-polysaccharide polymer consisting of phenylpropane units usually connected with polysaccharides especially hemicellulose at $\alpha$-carbon and C-4 sites of the benzene ring through covalent bonds [5]. Pre-treatment processes are mainly involved in effective separation of interlinked fractions and increase the accessibility of each individual component, thereby becoming an essential step in a broad range of applications. However, a major hurdle is the removal of sturdy and rugged lignin component which is highly resistant to solubilisation and is also a major inhibitor for hydrolysis of cellulose and hemicellulose [6].

The first report on transparent wood is from Fink in 1992 to facilitate wood morphology studies [7]. After that, several studies were published along similar engineering use considerations [8-10]. With the addition of optical transmittance to the basic wood properties, transparent wood facilitates wood anatomy studies [7], and it can be used in the light transmitting smart buildings [8,11, 12], electronic devices, and in photonic devices such as photovoltaic cells and light source [13-15]. Several contributions have also briefly discussed the transparent wood as a part of functionalized wood when reviewing the wood nanotechnologies $[16,17]$.

This has led to extensive research in the development of various pre-treatment processes. [6] It is also used during biofuel production, extraction of cellulose from wood to produce paper and in recent years to create a composite material of cellulose wood fibres and epoxy resin in a material with resulting extraordinary anisotropic optical and mechanical properties or the lightweight and low-cost structures in light transmitting and for transparent solar cell windows [12].

In 2016, the Zhu M. [18] research team was able to design the highly transparent wood composites, using macrostructure in original wood for the first time. These wood composites are highly transparent with a total transmittance of up to $90 \%$, but they show dramatically different optical and mechanical properties. In our research, we tried to contribute to the improvement of the processes, using modifications. This research will be followed by a study of fire-technical and acoustic properties of the given composite materials. There are no studies in this field up to date.

\section{MATERIALS AND METHODOLOGY OF EXPERIMENT}

Basswood wood (Tilia cordata) coming from the Trnava region, Slovakia, with a density of $480 \mathrm{~kg} \cdot \mathrm{m}^{-3}$ was dried at $100 \pm 3{ }^{\circ} \mathrm{C}$ for $48 \mathrm{~h}$ before chemical extraction. In our experiments, wood blocks from basswood of various dimensions, from $20 \times 20 \times 2 \mathrm{~mm}$ to $50 \times 50 \times 5 \mathrm{~mm}$, were used. All of the comparative experiments were conducted with samples of the same dimensions. Conventional processes and chemicals applied in the cellulose production were used. The main processes could by divided into two steps. During Step 1, the samples were soaked in boiling solution for a specific amount of time containing $\mathrm{NaOH}$ or $\mathrm{KOH}$ with $\mathrm{Na}_{2} \mathrm{SO}_{3}$ to dissolve a significant portion of the lignin. In Step 2 of the process, the samples were placed into the $\mathrm{H}_{2} \mathrm{O}_{2}$ solution to remove the remaining lignin. Since lignin is coloured while cellulose is colourless, the colour in the wood blocks indicates the amount of lignin present in the wood. 
The colour becomes lighter and more transparent as lignin was removed. The whole procedure is shown in Fig.1.

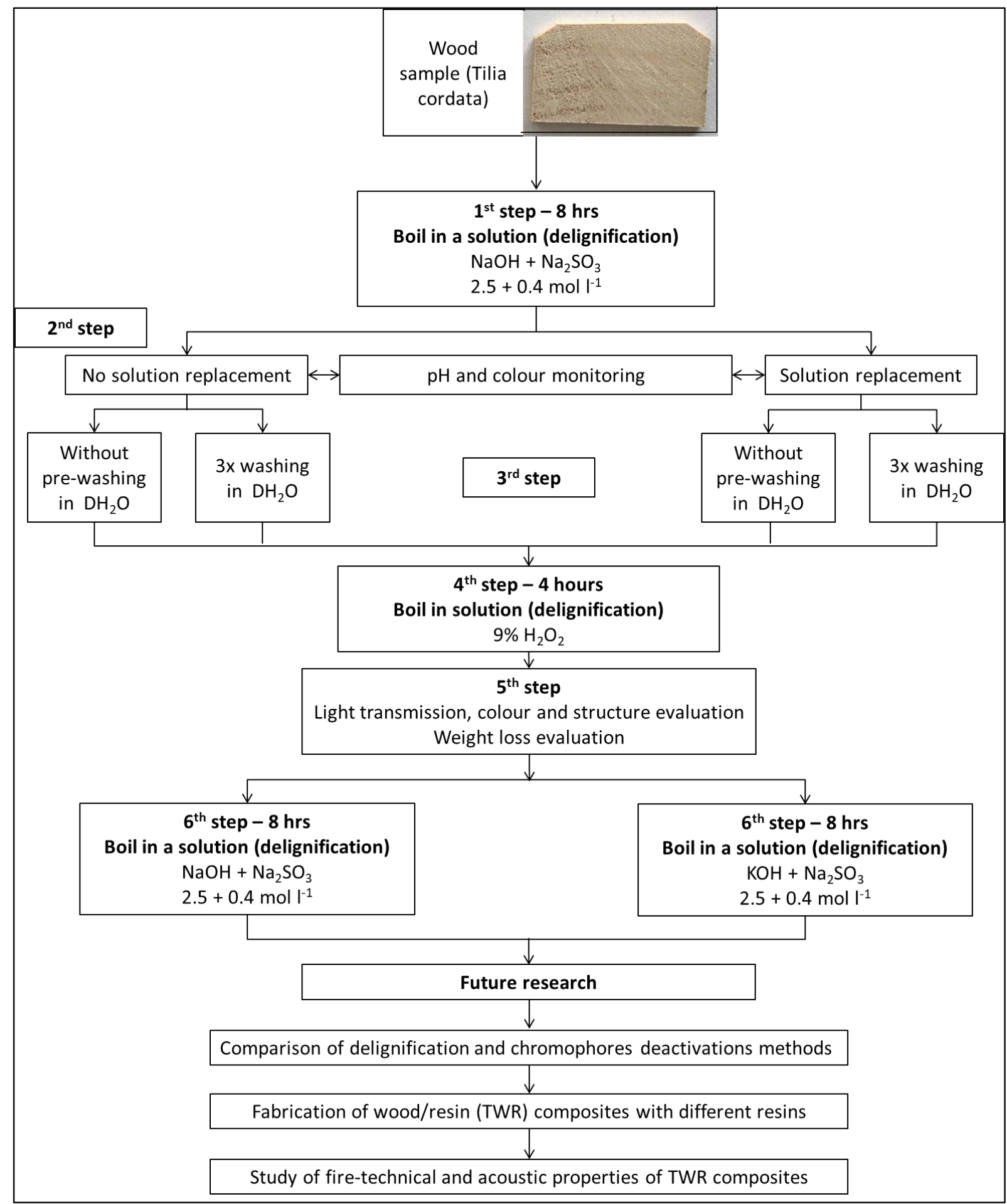

Fig. 1 Work scheme of performed experiments

Delignification of the samples was evaluated by the RMG 2.1 photometer chamber with LX1010BS luxmeter as an increment of the transmittance of the sample compared to the raw sample. Lignin content was also evaluated using a UV/VIS Spectrophotometer Termo GENESIS $^{\mathrm{TM}} 8$ as a change of absorbance of the $\mathrm{NaOH}$ solution after defined time. Individual absorbances were recorded in the range of $200-700 \mathrm{~nm}$ using a program RS-232 Access. 


\section{ATTAINED RESULTS AND DISCUSSION ON RESULTS}

In determining the processes occurring during the chemical extraction, Step 1 was intended to measure the weight of the samples during individual phases. The average weight loss after the first chemical bath $\left(\mathrm{NaOH}+\mathrm{Na}_{2} \mathrm{SO}_{3} ; 2.5 \mathrm{M}\right.$ and $\left.0.4 \mathrm{M}\right)$ reached $28 \%$. After the second chemical bath $\left(2.5 \mathrm{M} \mathrm{H}_{2} \mathrm{O}_{2} ; 3 \mathrm{~h}\right)$, the mass loss decreased to $56 \%$ which was probably due to the removal of almost all the lignin and the extractive substances from the wood. Samples exhibited a porous, fragile structure and were considerable whiter (Fig.2).

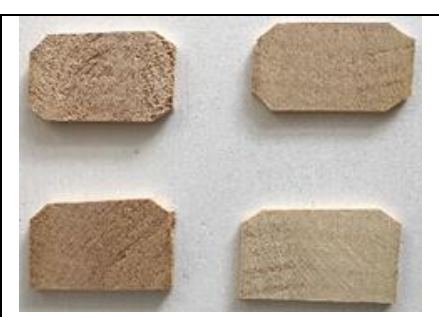

a)

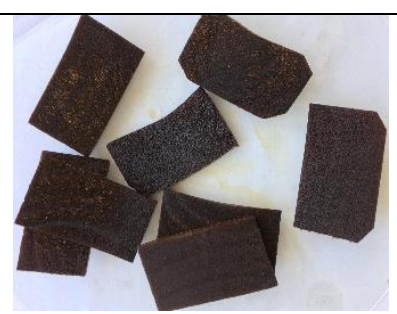

b)

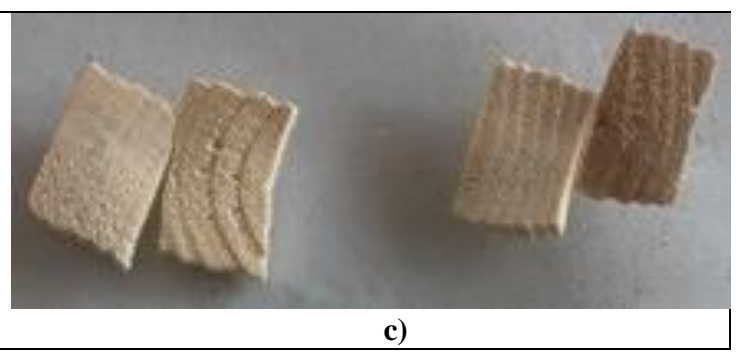

c)

Fig. 2 Weight loss evaluation a) Raw samples b) Samples after Step 1 c) Samples after Step 4

The aim of the Step 2 of the work scheme was to determine whether a change of the solution during the process and washing of the samples with boiling distilled water prior to chemical bath of hydrogen peroxide has an impact on the amount of removed lignin. The results are shown in Tab. 1. Having evaluated the data, we can assume that the most influential parameter on the total transmittance of the samples was the step of not pre-washing the samples with boiling distilled water prior to hydrogen peroxide bath. The maximum luminosity achieved by the device using only a $4 \mathrm{~cm}^{2}$ filter was of $143 \mathrm{~lx}$. Untreated samples were unable to transmit any light.

\begin{tabular}{|c|c|c|c|c|c|}
\hline \multicolumn{6}{|c|}{ Table 1 Transmittance results after Step 3} \\
\hline Num. & Parameters & $\begin{array}{c}\text { Thickness } \\
\text { of the } \\
\text { sample } \\
\text { (mm) }\end{array}$ & $\begin{array}{c}\text { Luminosity } \\
\text { per } 4 \mathrm{~cm}^{2} \\
(\mathbf{l x})\end{array}$ & $\begin{array}{l}\text { Average } \\
\text { luminosity } \\
(\mathbf{l x})\end{array}$ & $\begin{array}{c}\text { Transmittance } \\
{[\%]}\end{array}$ \\
\hline \multirow{3}{*}{1.} & \multirow{3}{*}{$\begin{array}{l}\text { Without change of } \\
\text { solution, washed } \\
\text { with boiling water }\end{array}$} & 4 & 36 & \multirow{3}{*}{40} & \multirow{3}{*}{27.97} \\
\hline & & 4 & 40 & & \\
\hline & & 2 & 43 & & \\
\hline \multirow{3}{*}{2.} & \multirow{3}{*}{$\begin{array}{l}\text { Changed solution, } \\
\text { washed with } \\
\text { boiling water }\end{array}$} & 4 & 40 & \multirow{3}{*}{42} & \multirow{3}{*}{29.37} \\
\hline & & 4 & 40 & & \\
\hline & & 2 & 46 & & \\
\hline \multirow{3}{*}{3.} & \multirow{3}{*}{$\begin{array}{l}\text { Without change of } \\
\text { solution, without } \\
\text { pre-washing with } \\
\text { boiling water }\end{array}$} & 4 & 55 & \multirow{3}{*}{66} & \multirow{3}{*}{46.15} \\
\hline & & 2 & 74 & & \\
\hline & & 2 & 69 & & \\
\hline \multirow{3}{*}{4.} & \multirow{3}{*}{$\begin{array}{l}\text { Changed solution, } \\
\text { without pre- } \\
\text { washing with } \\
\text { boiling water }\end{array}$} & 4 & 47 & \multirow{3}{*}{60} & \multirow{3}{*}{41.95} \\
\hline & & 2 & 63 & & \\
\hline & & 2 & 69 & & \\
\hline
\end{tabular}


Figure 3 shows the difference of colour shade after the above-mentioned procedure. The lighter colour of samples on the right was caused by the lower lignin content in the whole volume.
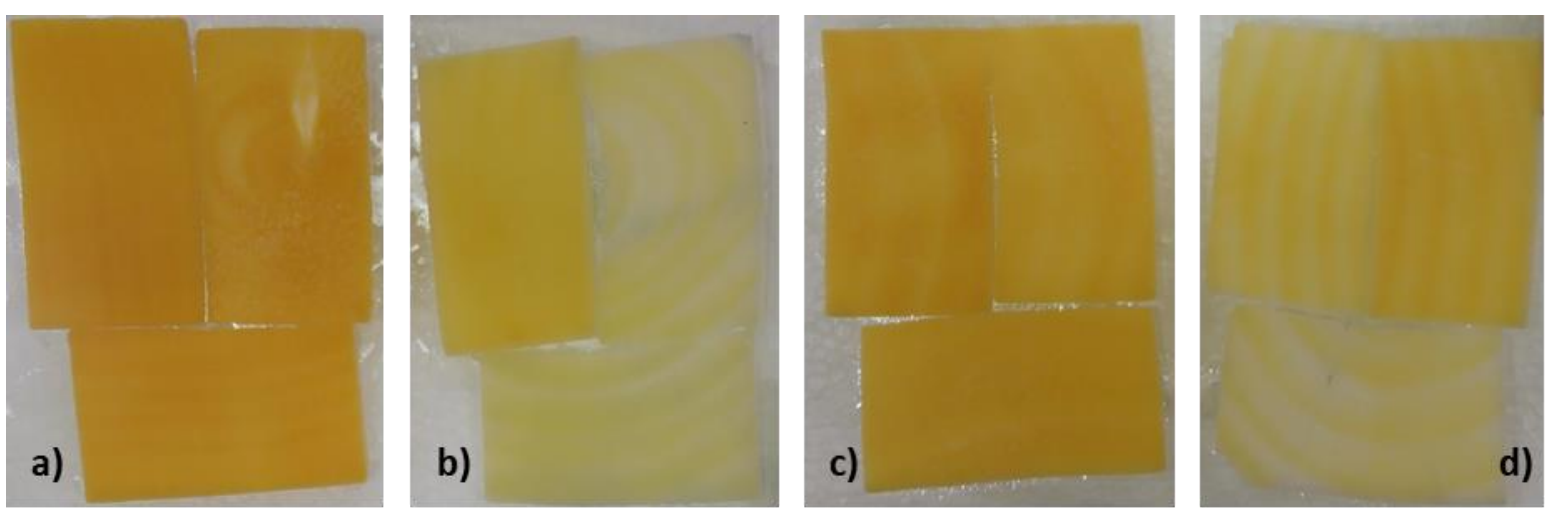

Fig. 3 Samples after Step 2 of delignification process; $1.25 \mathrm{M} \mathrm{NaOH}+0.4 \mathrm{M} \mathrm{Na}_{2} \mathrm{SO}_{3}$; treatment time 8 hrs; a) WO solution change, washed; b) WO solution change, not washed; $c$ ) W solution change, washed; d) W solution change, not washed (author)

The purpose of the Step 6 of the work scheme was to compare the effectiveness of two different alkali solutions: 1 . Solution of $\mathrm{NaOH}(2.5 \mathrm{M})+\mathrm{Na}_{2} \mathrm{SO}_{3}(0.4 \mathrm{M}) ; 2$. Solution of $\mathrm{KOH}$ $(2.5 \mathrm{M})+\mathrm{Na}_{2} \mathrm{SO}_{3}(0.4 \mathrm{M})$. The experiment lasted for $8 \mathrm{hrs}$. The results (Tab. 2) showed that the solution containing potassium hydroxide resulted in a higher total luminosity of the samples which means that the lignin content was lower however the difference was not substantial. The maximum luminosity achieved by the device using only a $4 \mathrm{~cm}^{2}$ filter was of $131 \mathrm{~lx}$. Untreated samples were unable to transmit any light.

\begin{tabular}{|c|c|c|c|c|c|}
\hline Num. & Parameters & $\begin{array}{c}\text { Avg. sample } \\
\text { thickness } \\
(\mathrm{mm})\end{array}$ & $\begin{array}{c}\text { Luminosity } \\
\text { per } 4 \mathrm{~cm}^{2} \\
(\mathrm{~lx})\end{array}$ & $\underset{(\mathbf{l x})}{\text { Avg. }}$ & $\begin{array}{c}\text { Transmittance } \\
{[\%]}\end{array}$ \\
\hline \multirow{6}{*}{1.} & \multirow{6}{*}{$\begin{array}{c}\mathrm{NaOH}(2.5 \mathrm{M})+ \\
\mathrm{Na}_{2} \mathrm{SO}_{3}(0.4 \mathrm{M})\end{array}$} & \multirow{6}{*}{3} & 58 & \multirow{3}{*}{55} & \multirow{3}{*}{41.98} \\
\hline & & & 55 & & \\
\hline & & & 55 & & \\
\hline & & & 47 & \multirow{3}{*}{50} & \multirow{3}{*}{38.17} \\
\hline & & & 50 & & \\
\hline & & & 53 & & \\
\hline \multirow{6}{*}{2.} & \multirow{6}{*}{$\begin{array}{l}\mathrm{KOH}(2.5 \mathrm{M})+ \\
\mathrm{Na}_{2} \mathrm{SO}_{3}(0.4 \mathrm{M})\end{array}$} & \multirow{6}{*}{3} & 59 & \multirow{3}{*}{56} & \multirow{3}{*}{42.75} \\
\hline & & & 55 & & \\
\hline & & & 54 & & \\
\hline & & & 61 & \multirow{3}{*}{59} & \multirow{3}{*}{45.04} \\
\hline & & & 60 & & \\
\hline & & & 57 & & \\
\hline
\end{tabular}

Two different approaches to lignin removal were also compared. Approach 1 consisted of $6 \mathrm{hrs}$ of boiling in the chemical bath of $\mathrm{NaOH}(2.5 \mathrm{M})+\mathrm{Na}_{2} \mathrm{SO}_{3}(0.4 \mathrm{M})$ with subsequent boiling in $9 \%$ hydrogen peroxide for $1.5 \mathrm{~h}$. Approach 2 consisted of three cycles of $2 \mathrm{hrs}$ boiling in a chemical bath of $\mathrm{NaOH}(2.5 \mathrm{M})+\mathrm{Na}_{2} \mathrm{SO}_{3}(0.4 \mathrm{M})$ with subsequent boil in a $9 \%$ hydrogen peroxide for $0.5 \mathrm{~h}$. The total amount of time spent in baths as well as the chemical substances 
and their ratios were equal. The results were compared based on the luminosity of the samples. The maximum luminosity achieved by the device using only a $4 \mathrm{~cm}^{2}$ filter was of $130 \mathrm{~lx}$. Tab.3 shows that better results were obtained by Approach 1 and that the repetition of cycles does not provide any advantage.

\begin{tabular}{|c|c|c|c|c|}
\hline Num. & Parameters & Chemicals & $\begin{array}{l}\text { Luminosity per } \\
4 \mathrm{~cm}^{2}(\mathbf{l x})\end{array}$ & $\begin{array}{c}\text { Average } \\
\text { luminosity } \\
(\mathbf{l x})\end{array}$ \\
\hline \multirow{5}{*}{1.} & \multirow{5}{*}{$6 h+1.5 h$} & \multirow{5}{*}{$\begin{array}{c}\left(\mathrm{NaOH}(2.5 \mathrm{M})+\mathrm{Na}_{2} \mathrm{SO}_{3}\right. \\
(0.4 \mathrm{M}))+2.5 \mathrm{M} \mathrm{H}_{2} \mathrm{O}_{2}\end{array}$} & 42 & \multirow{5}{*}{48} \\
\hline & & & 47 & \\
\hline & & & 57 & \\
\hline & & & 56 & \\
\hline & & & 39 & \\
\hline \multirow{5}{*}{2.} & \multirow{5}{*}{$3 \times(2 h+0.5 h)$} & \multirow{5}{*}{$\begin{array}{c}\left(\mathrm{NaOH}(2.5 \mathrm{M})+\mathrm{Na}_{2} \mathrm{SO}_{3}\right. \\
(0.4 \mathrm{M}))+2.5 \mathrm{M} \mathrm{H}_{2} \mathrm{O}_{2}\end{array}$} & 36 & \multirow{5}{*}{40} \\
\hline & & & 36 & \\
\hline & & & 34 & \\
\hline & & & 48 & \\
\hline & & & 46 & \\
\hline
\end{tabular}

The effect of the amount of sodium hydroxide in the solution on lignin removal is shown in Table 4. From the obtained results, we can assume that by increasing the amount of sodium hydroxide the efficacy of lignin removal did not increase. In a similar experiment, the effect of the amount of sodium sulphite in the solution on lignin removal showed similar results; i.e. it is not desirable to increase the amount of sodium sulphite over $0.4 \mathrm{M}$.

\begin{tabular}{|c|c|c|c|}
\hline Num. & Parameters & $\begin{array}{c}\text { Luminosity per } \\
4 \mathrm{~cm}^{2}(\mathbf{l x})\end{array}$ & $\begin{array}{c}\text { Average } \\
\text { luminosity (lx) }\end{array}$ \\
\hline \multirow{6}{*}{1.} & \multirow{6}{*}{$\mathrm{NaOH}(2.5 \mathrm{M})+\mathrm{Na}_{2} \mathrm{SO}_{3}(0.4 \mathrm{M})$} & 58 & \multirow{6}{*}{53} \\
\hline & & 47 & \\
\hline & & 55 & \\
\hline & & 51 & \\
\hline & & 51 & \\
\hline & & 54 & \\
\hline \multirow{6}{*}{2.} & \multirow{6}{*}{$\mathrm{NaOH}(3.75 \mathrm{M})+\mathrm{Na}_{2} \mathrm{SO}_{3}(0.4 \mathrm{M})$} & 57 & \multirow{6}{*}{48} \\
\hline & & 50 & \\
\hline & & 41 & \\
\hline & & 44 & \\
\hline & & 44 & \\
\hline & & 50 & \\
\hline \multirow{6}{*}{3.} & \multirow{6}{*}{$\mathrm{NaOH}(5.00 \mathrm{M})+\mathrm{Na}_{2} \mathrm{SO}_{3}(0.4 \mathrm{M})$} & 61 & \multirow{6}{*}{49} \\
\hline & & 36 & \\
\hline & & 48 & \\
\hline & & 59 & \\
\hline & & 44 & \\
\hline & & 45 & \\
\hline
\end{tabular}


Fig. 4 shows the absorbance curves of lignin removal solution $\left(\mathrm{NaOH}(2.5 \mathrm{M})+\mathrm{Na}_{2} \mathrm{SO}_{3}\right.$ $(0.4 \mathrm{M}))$ in the spectrum range of $200-700 \mathrm{~nm}$ at selected time. We assume that the lignin content in solution increased with increasing the time of bath. The highest lignin removal was achieved after first and second hour of the experiment duration.

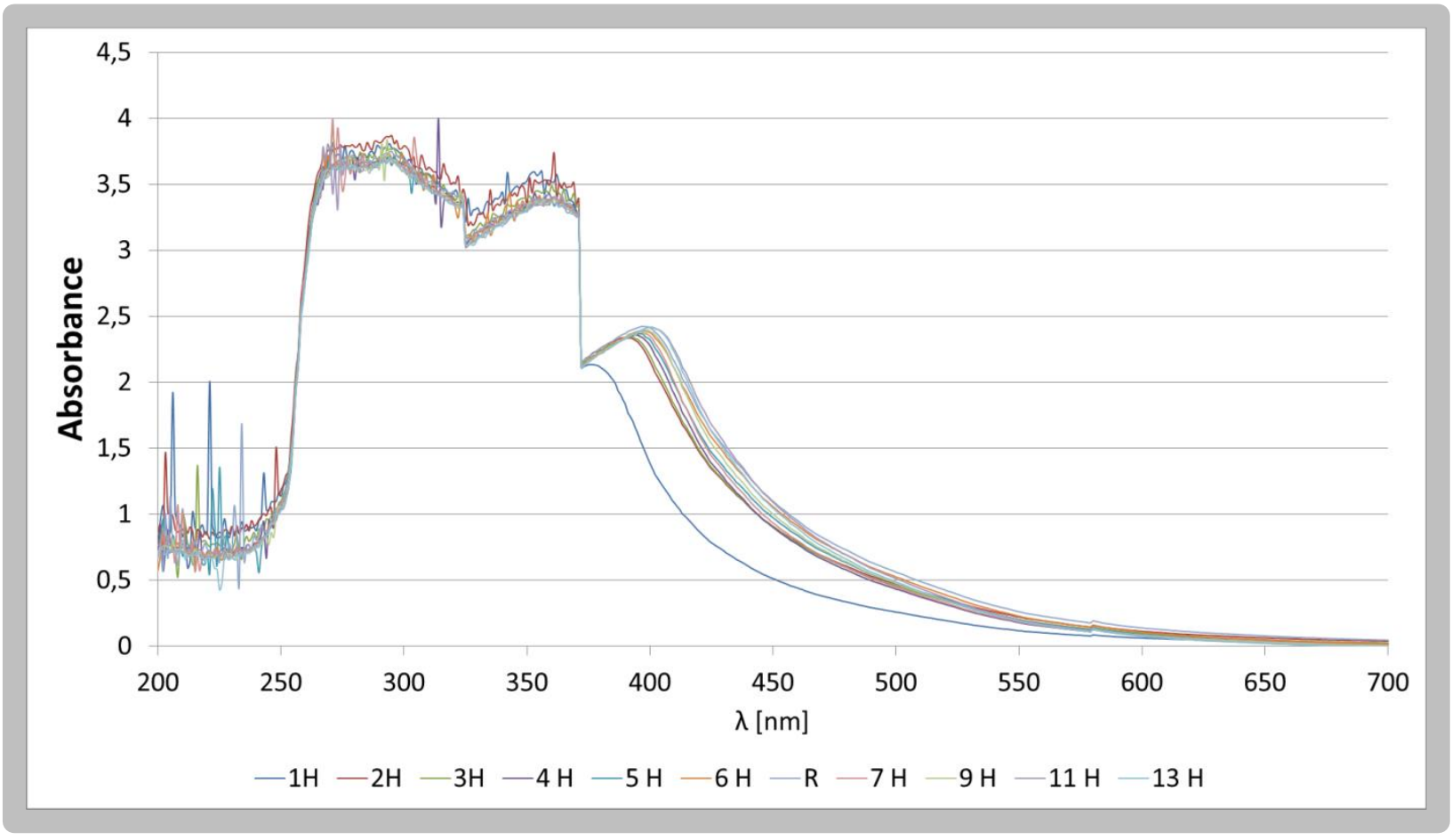

Fig. 4 UV/VIS spectrum of lignin removal solution, after selected time, in the range of $200-700 \mathrm{~nm}$

Fig. 5 shows the delignified samples of basswood of different thickness: a) $3 \mathrm{~mm}$ sample, b) $0.5 \mathrm{~mm}$ sample. Hydrogen peroxide was used to remove the residual lignin. According to literature, the final product of these treatments provided the "white colour" lignin content under approx. 3\%. These samples were then stored in pure ethanol to remove water and to stabilize the samples before further use. Dried samples of various dimensions and shapes are shown in Fig. 5c. Samples were dried in the air at normal conditions and their colour turned white due to the lack of natural polymer - lignin.
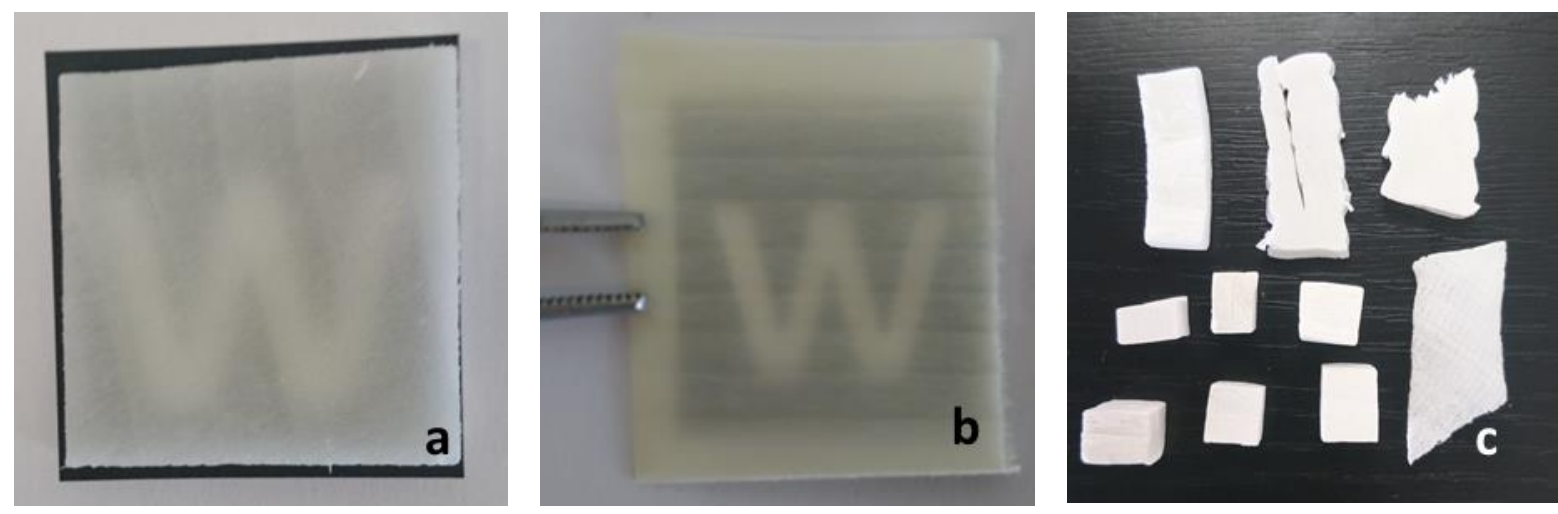

Fig. 5 Final examples of delignified basswood samples: a) $3 \mathrm{~mm}$ thick, radially-cut sample b) $0.5 \mathrm{~mm}$ thick, radially-cut sample c) dried samples of various dimensions and shapes 


\section{CONCLUSION}

Optically transparent wood-resin composite (WRC) is a promising material of extraordinary properties in many fields and applications. During the last few years, dozens of papers have recorded the progress achieved in all of the most important steps of wood-resin composites preparation. In summary, we optimized the basic sulphur process of lignin removal from the raw radially cut basswood pieces of various thicknesses, which is a key pre-step to the WRC manufacturing. Experimentally, we were able to prove that the change of fresh $\mathrm{NaOH}+$ $\mathrm{Na}_{2} \mathrm{SO}_{3}$ solution during the experiment had no significant effect on lignin removal. In contrast, omitting the washing of the samples with boiling distilled water after the hydroxide bath had a significant effect on the rate and efficiency of lignin removal with $\mathrm{H}_{2} \mathrm{O}_{2}$ in the following step. When comparing the lignin removal efficiency of $\mathrm{NaOH}+\mathrm{Na}_{2} \mathrm{SO}_{3}$ and $\mathrm{KOH}+\mathrm{Na}_{2} \mathrm{SO}_{3}$, the delignification process was clearly demonstrated to be more effective when using $\mathrm{KOH}+$ $\mathrm{Na}_{2} \mathrm{SO}_{3}$ solution. This research will be followed by studying the new, eco-friendly and efficient methods of bleaching raw wood and simultaneously to study fire-technical and acoustic properties of the given composite material, since there are no studies in this field to date.

\section{Acknowledgement}

This research output was supported by the Slovak Research and Development Agency under the contract No. APVV-16-0223.

This research output was supported by the Cultural and Education Agency of the Ministry of Education, Science, Research and Sport of the Slovak Republic (KEGA 030UMB-4/2017).

\section{References}

[1] PAJCHROWSKI, G., NOSKOWIAK, A., LEWANDOWSKA, A., STRYKOWSKI, W. 2014. Wood as a building material in the light of environmental assessment of full life cycle of four buildings. Construction and Building Materials [online]. 2014, 52, 428-436. ISSN 0950-0618. Available at: doi:https://doi.org/10.1016/j.conbuildmat.2013.11.066

[2] PRENTICE, I. C., FARQUHAR, G. D., FASHAM, M. J. R., GOULDEN M. L., HEIMANN, M., JARAMILLO, V. J., KHESHGI, H. S., LE QUÉRÉ, C., SCHOLES, R. J., WALLACE, D. W. R. 2001. The carbon cycle and atmospheric carbon dioxide in climate change 2001. In: HOUGHTON, J. T., DING, Y., GRIGGS, D. J., NOGUER, M., VAN DER LINDEN, P. J., DAI, X., MASKELL, K., JOHNSON, C. A.. CLIMATE CHANGE 2001: THE SCIENTIFIC BASIS. Cambridge: CAMBRIDGE UNIVERSITY PRESS, p. 183-238.

[3] RUSSELL P. A., GRAY, R. L. 1984. Formation and Structure of Wood. In: The Chemistry of Solid Wood. [online]. B.m.: American Chemical Society, p. 1-3. ISBN 0-8412-0796-8. Available at: doi:doi:10.1021/ba-1984-0207.ch001

[4] ANSELL, M. P. 2015. 1 - Wood microstructure - A cellular composite. In: Wood Composites [online]. Woodhead Publishing, p. 3-26. ISBN 978-1-78242-454-3. Available at: doi:https://doi.org/10.1016/B978-1-78242-454-3.00001-9

[5] BURANOV, A. U., MAZZA, G. 2008. Lignin in straw of herbaceous crops. Industrial Crops and Products [online]. 28(3), p. 237-259. ISSN 0926-6690. Available at: doi:10.1016/j.indcrop.2008.03.008

[6] KUMAR, A. K., SHARMA, S. 2017. Recent updates on different methods of pretreatment of lignocellulosic feedstocks: a review. Bioresources and bioprocessing [online]. 2017/01/18. 2017, 4(1), 7. ISSN 2197-4365. Available at: doi:10.1186/s40643-017-0137-9

[7] FINK, S. 1992. Transparent Wood - A New Approach in the Functional Study of Wood Structure [online]. ISBN 1437434. Available at: doi:10.1515/hfsg.1992.46.5.403

[8] ZHU, M., LI, T., DAVIS, Ch. S., YAO, Y., DAI, J., WANG, Y., ALQATARI, F., GILMAN, J.W., HU, J. 2016. Transparent and haze wood composites for highly efficient broadband light 
management in solar cells. Nano Energy [online]. 26, p. 332-339. ISSN 2211-2855. Available at: doi:https://doi.org/10.1016/j.nanoen.2016.05.020

[9] YU, Z., YAO, Y., YAO, J., ZHANG, L., CHEN, Z., GAO, Y., LUO, H. 2017. Transparent wood containing CsxWO3 nanoparticles for heat-shielding window applications. Journal of Materials Chemistry A [online]. 2017, 5(13), p. 6019-6024. ISSN 2050-7488. Available at: doi:10.1039/C7TA00261K

[10] GAN, W., GAO, L., XIAO, S., ZHANG, W., ZHAN, X., LI, J. 2017. Transparent magnetic wood composites based on immobilizing $\mathrm{Fe} 3 \mathrm{O} 4$ nanoparticles into a delignified wood template. Journal of Materials Science [online]. 52(6), p. 3321-3329. ISSN 1573-4803. Available at: doi:10.1007/s10853-016-0619-8

[11] LI, Y., FU, Q., ROJAS, R., YAN, M., LAWOKO, M., BERGLUND, L. 2017. Lignin-Retaining Transparent Wood. ChemSusChem [online]. 10(17), p. 3445-3451. ISSN 1864-5631. Available at: doi:10.1002/cssc.201701089

[12] LI, Y., FU, Q., YU, S., YAN, M., BERGLUND, L. 2016. Optically Transparent Wood from a Nanoporous Cellulosic Template: Combining Functional and Structural Performance. Biomacromolecules [online]. 17(4), p. 1358-1364. ISSN 1525-7797. Available at: doi:10.1021/acs.biomac.6b00145

[13] VASILEVA, E., LI, Y., SYCHUGOV, I., MENSI, M., BERGLUND, L., POPOV, S. 2017. Lasing from Organic Dye Molecules Embedded in Transparent Wood. Advanced Optical Materials [online]. 5(10), 1700057. ISSN 2195-1071. Available at: doi:10.1002/adom.201700057

[14] LI, T., ZHU, M., YANG, Z., SONG, J., DAI, J., YAO, Y., LUO, W., PASTEL, G., YANG, B., HU, L. 2016. Wood Composite as an Energy Efficient Building Material: Guided Sunlight Transmittance and Effective Thermal Insulation. Advanced Energy Materials [online]. 6(22), 1601122. ISSN 1614-6832. Available at: doi:10.1002/aenm.201601122

[15] LI, Y., YU, S., VEINOT, J. G. C., LINNROS, J., BERGLUND, L., SYCHUGOV, I. 2017. Luminescent Transparent Wood. Advanced Optical Materials [online]. 5(1), 1600834. ISSN 21951071. Available at: doi:10.1002/adom.201600834

[16] JIANG, F., LI, T., LI, Y., ZHANG, Y., GONG, A., DAI, J., HITZ, E., LUO, W., HU, L. 2018. Wood-Based Nanotechnologies toward Sustainability. Advanced Materials [online]. 30(1), 1703453. ISSN 0935-9648. Available at: doi:10.1002/adma.201703453

[17] BERGLUND, L., BURGERT, I. 2018. Bioinspired Wood Nanotechnology for Functional Materials. Advanced Materials [online]. 30(19), 1704285. ISSN 0935-9648. Available at: doi:10.1002/adma.201704285

[18] ZHU, M., SONG, J., LI, T., GONG, A., WANG, Y., DAI, J., YAO, Y., LUO, W., HENDERSON, D., HU, L. 2016. Highly Anisotropic, Highly Transparent Wood Composites. Advanced Materials [online]. 28(26), 5181-5187. ISSN 0935-9648. Available at: doi:10.1002/adma.201600427 